\title{
Quantification and Diminution of Quercus semecarpifolia Forests Ecosystem Services in Himalayan Region- An Overview
}

\author{
Chander Shekhar*, H.S. Ginwal, M.S. Bhandari and Santan Barthwal
}

Division of Genetics and Tree Improvement, Forest Research Institute, Dehradun, India

*Corresponding author: chandershekhargenetics@gmail.com (ORCID ID: 0000-0001-6935-7217)

Paper No. 884

Received: $14-01-2021$

Revised: 20-02-2021

Accepted: 08-03-2021

\begin{abstract}
The genus Quercus comprises very important tree species of the Himalayan forests. Oaks are crucial for a multitude of ecosystem services and livelihood support services reaped by the locals in the Himalayan region. Quercus semecarpifolia is the oldest and dominating species of the Himalayan region. It is considered a lifeline for people of this region due to the wider range of ecosystem and livelihood services provided by it. But this species forest is depleting very rapidly in his region due to over dependency. Major cause of overexploitation is lopping for fodder and fuelwood. The present study attempted to Quantify, recognize, and group the ecosystem services provided by Q. semecarpifolia. Further, certain factors responsible for regular shrinkage of $Q$. semecarpifolia forests were also addressed.

\section{Highlights}

0 Ecosystem services of Quercus semecarpifolia forests were quantified and recognized.

- Quercus semecarpifolia forests in certain Himalayan Region are overexploited and threatened mainly due to anthropogenic disturbances.

0 Quantification, valuation, and prioritization of Forests Ecosystem services derived from the other ecosystems of Himalaya is still in its commencement.
\end{abstract}

Keywords: Quercus semecarpifolia, ecosytem services, quantification, himalayan region, inaccessibility, Anthropogenic disturbances

Mankind relies upon numerous ecosystem services provided by forest ecosystems. These services are invaluable and contribute to human survival and quality of life. Ecosystem services have received global attention due to recognition in the last few years because of their role in supporting rural livelihoods and reducing climate vulnerabilities in developing and underdeveloped countries. Due to undulating topography and remoteness, for centuries, inhabitants of the Himalayas are also relying mainly on the Himalayan natural resources for livelihood and regulating services. Himalayan forests harbor diversified flora and mountain ecosystems (Singh 2006). High altitude broadleaved forests form the most substantial ecosystems in the Himalayan region. Oaks form climax vegetation and dominate moist temperate forests of the Indian
Himalayan region (Troup 1921). Approximately 35 oak species were reported and spread at elevations between 800 to $3800 \mathrm{~m}$ AMSL (above mean seal level) throughout the Himalaya in the Himalayan region (Negi and Naithani 1995).

Among Himalayan oaks, Q. semecarpifolia, generally recognized as 'Kharsu' or brown oak, is the key forest forming tree species of upper temperate to sub-alpine regions (2500-3300 m) (Singh and Singh 1992). It is dominating vegetation of 1 million ha of forest in the mountains and spread from southwest china to Afghanistan in the Himalayan

\footnotetext{
How to cite this article: Shekhar, C., Ginwal, H.S., Bhandari, M.S and Barthwal, S. 2021. Quantification and Diminution of Quercus semecarpifolia Forests Ecosystem Services in Himalayan Region- An Overview. IJAEB, 14(1): 83-87.

Source of Support: None; Conflict of Interest: None
} 
region (Singh 1996). These regions are remote and inaccessible, so communities of this region are deprived of employment and access to modern technologies. Oak species serve as a lifeline for the local communities in the Himalayan region because they are linked with agroecosystems and provide valuable livelihood services to these communities (Upreti et al. 1985; Singh and Singh 1986). Q. semecarpifolia serves numerous ecosystem services, which are significant, especially for the livelihood of inhabitants of the sub-alpine and alpine region. Despite the provision of multiple valuable services, Q. semecarpifolia,s forests in certain Himalayan Region are overexploited and threatened. Populations of $Q$. semecarpifolia are seriously threatened in Himalayas by several factors, the most important of which are of anthropogenic origin. In combination with an innately slow growth rate, this species is degrading and shrinking in the Himalayan region (Shrestha 2003; Subedi 2006).

As a consequence, ecosystem services of $Q$. semecarpifolia forests have reduced considerably in recent decades and subsequently require consideration and suitable conservation efforts. Conventionally forest ecosystem services were thought of as a 'gift of nature' and utilized throughout generations, though their quantification, recognition, and economic valuation are often ignored or underestimated. In this review, an attempt was made to Quantify, recognize and group the ecosystem services provided by $Q$. Semecarpifolia forests in the Himalayan region. It is expected that review of this species will enhance the human wellbeing in this region by conservation and suitable management of $Q$. semecarpifolia ecosystems.

\section{Quercus semecarpifolia and the Ecosystem Services it Provides}

Ecosystem services of $Q$. semecarpifolia were quantified, recognized, and grouped according to (De groot et al. 2010).

\section{Provisioning services}

(a) Fuelwood: Trees have been used for centuries as fuel globally (Smith 1992; Kababya et al. 1998; Perevolotsky et al. 1998). Fuelwood is an essential component of household economies in the Himalayas. Q. semecarpifolia is an important fuel to these people living in remote areas (Shrestha
2003). Large branches are preferred as firewood and charcoal possess high calorific value (Orwa et al. 2009).

(b) Fodder: Tree leaves are an important feed of livestock (Holechek 1984; Papachristou \& Nastis 1996; Saklani 1999) and play an important role in the nutrition of livestock in areas where few or no alternatives are available (Meuret et al. 1990). As in many other regions of the world, a farmer in the mountainous region of Indian Himalaya relies heavily on this resource for sustaining their livestock for almost half of the year. Q. semecarpifolia supplies dry season fodder to Himalayan People when there is a scarcity of green fodder (Orwa et al. 2009; Singh and Todaria 2012). But public forests are heavily lopped continuously whole year by farmers to fulfill forage demands (Shrestha and Paudel 1996).

(c) Leaf litter (natural fertilizer): The Himalayan population is rural, agrarian, and dependent on conventional agriculture for livelihood. Generally, Hill agriculture is reliant upon leaf litter for natural fertilizer rather than chemical fertilizers. $Q$. semecarpifolia,s is among those species whose leaf litter is used by hill farmers for making compost (Shrestha 2003; Roder et al. 2003).

(d) Non-timber forest products: Humans have been provisioned by Oak trees with goods and services for centuries, from the ink for writing that comes from tannins in the bark. Q. semecarpifolia's bark is an important source of tannin (Pandey and Makkar 1991). Galls produced in great numbers on the tree due to larval activity of insects are tannin's source (Orwa et al. 2009).

(e) Timber: $Q$. semecarpifolia's wood is strong, fine, and durable in nature. Its wood can be easily shaped and used for furniture work and agricultural implements (Shrestha 2003). Heartwood is reddishgrey in color and hard, but annual rings are not very distinct. Weight $850 \mathrm{~kg} / \mathrm{cum}$. The wood is found to split on seasoning. Wood is also in demand by distilleries as a substitute for imported oak for kegs (Orwa et al. 2009).

(f) Food: Q. semecarpifolia dominates forests of temperate and sub-alpine and supplies food to a wide range of fauna. The acorns are consumed as food by many wild animals like bears, monkeys, squirrels, and birds (Shrestha 2003). Seeds can be 
dried or ground into a powder and further mixing with cereals for making bread (Orwa et al. 2009).

\section{Regulating services}

Generally regulating services of oaks are perhaps well recognized than their provisioning services. But In the climax community $Q$. semecarpifolia is a keystone species, where it has to play a crucial role in balancing the environment at both local and regional levels.

(a) Maintaining Soil fertility: Q. semecarpifolia forests produce plenty of litter which forms spongelike formation. This plentiful litter production helps in sustaining soil fertility and checks soil erosion (Shrestha 2003; Roder et al. 2003). The decomposition rate (\% weight loss) of leaf litter was highest for $Q$. semecarpifolia oak (74\%) after 3 years in treeline ecotones of Kedarnath Wildlife Sanctuary in Western Himalaya (Rai et al. 2020).

(b) Water regulation: Recharge of mountain springs is also regulated and promoted by Oaks (Valdia 1998). Due to their sponge-like nature, the Forests of $Q$. semecarpifolia helps in the retention of moisture for a long time, which helps in regulating the hydrology cycle and provides water to the rivulets.

\section{Habitat services}

(a) Maintenance of genetic diversity: $Q$. semecarpifolia provides microclimate and food for a wide range of flora and fauna. The closed canopy is necessary for the luxuriant growth of shade demanding ground vegetation. Mature tree branches support the growth of many vascular and epiphytes (Shrestha 2003). Certain patches of the forest in Bhutan were conserved, protected, and devoted to local gods and goddesses. These forest areas harbor a great deal of biodiversity, and trees here act as mother trees for seed production (Dorji et al. 2018).

\section{Cultural \& amenity services}

(a) Spiritual experience: Some forests are preserved as the abode of local deities and well-known for spiritual experiences. An example is of $Q$. semecarpifolia single tree recognized by the name "Gomju drake". This great oak is assumed to be more than a thousand years old and situated in the middle of Sheling village, Khotokha, Bhutan. Local people trust that this tree is dominated by a brutal local deity and if someone harms the tree deliberately or even unintentionally experience brutal illness (Dorji et al. 2018).

\section{Reduction of Quercus semecarpifolia Forest Ecosystem Services}

The Himalayas are home to human settlements and have been living for centuries. Numerous ecosystem services and livelihood support services of $Q$. semecarpifolia are significant for the Himalayan people. But presently, it is amongst one of the most exploited species in the Himalayan region. Anthropogenic activities like lopping for fuelwood and fodder are major threats to $Q$. semecarpifolia forests. Dependency on this species for fodder and firewood is so high that, in public forests, heavy and random lopping continues all over the year (Shrestha and Paudel 1996). The evergreen leaves of the $Q$. semecarpifolia are an important source of forage of livestock during the dry winters. Trees are reduced to naked poles to meet the demand for dry season fodder. Moreover, due to its higher calorific value of $Q$. semecarpifolia's wood, it is also used as fuelwood. Due to heavy lopping, trees are not able to produce abundant seeds, which leads to poor regeneration. Realizing the exploitation and decline in Q. semecarpifolia population in the 2000s, the Bhutan government has prohibited the felling of this species (Moktan 2014).

Altogether Q. semecarpifolia forest is degrading and shrinking in the Himalayan region. Consequently, it is attributed to over-utilization and a natural slow growth rate (Mathema 1991; Shrestha and Paudel 1996; Shrestha 2003; Dorji 2018). Degrading and shrinking in the population structure of this species has been linked to climate change (Upreti et al. 1985), but there is no population dynamics data to support this hypothesis. Depletion of this species may lead to a reduction of fodder, firewood manure, and timber. Due to shortage of fodder, farmers may give up the practice of animal keeping and ultimately reduction of crop production in this region (Shrestha and Paudel 1996). Himalayan people are mainly rural and agrarian; maintaining soil fertility with minimum chemical fertilizer inputs is their priority. Forest fodder and leaf litter are necessary for transferring nutrients from forests to agricultural fields (Roder et al. 2003). So due to the dearth of leaf litter and fodder, farmers may 
further give up conventional methods of cultivation. Further distribution of many bryophytes, epiphytes, and fauna depends on the microclimate provided by this species. Being a keystone species disturbance in its habitats may lead to the extinction of dependents like epiphytic plants, ground vegetation, and fauna.

\section{CONCLUSION}

This review emphasizes the quantification and reduction of important broad-leaved forest ecosystem services of $Q$. semecarpifolia in the Himalayan region. A review of literature reveals that ecosystem studies conducted in the Himalayas were dedicated only towards provisioning services, and other ecosystem services like regulating, habitat services and Cultural services are ignored due to their indirect benefits to communities. Conclusively 10 different types of ecosystem services were quantified and review of a certain degree of disturbances causing depletion of this species. Moreover, the present study can be used to address several research questions like $Q$. semecarpifolia forests depleting rapidly under the influence of anthropogenic disturbances. So, in a nutshell, there is a need to carry out comprehensive research of Himalayan forest ecosystem services on all important components of namely quantification, valuation, prioritization, and socio-cultural values. Quantification, valuation, and prioritization of Ecosystem services derived from the forests and other ecosystems of Himalaya are still in their inception and may need several years of research. Our study provides baseline data to address future comparisons, conservation, management, and reduction in ecosystem services of this species in the Himalayan region.

\section{REFERENCES}

Degroot, R.S., Fisher, B., Christie, M., Aronson, J., Braat, L., Haines-Young, R., Gowdy, J., Maltby, E., Neuville, A., Polasky, S., Portela, R. and Ring, I. 2010. Integrating the ecological and economic dimensions in biodiversity and ecosystem service valuation. In: Kumar P, editor. The economics of ecosystems and biodiversity: ecological and economic foundations. London (UK): Earthscan, p. 1-40.

Dorji, T., Baral, H., Brookes, J., Facelli, J., Sears, R., Norbu, T. and Dorji, K. 2018. Community values and perceptions of ecosystem services of high-altitude old-growth oak forests of Bhutan Himalayas. Working Paper 245. Bogor, Indonesia: CIFOR.

Holecheck, J.L. 1984. Comparative contribution of grasses, forbs, and shrubs to the nutrition range ungulates.
Rangelands, 6: 261-263.

Kababya, D., Perevolotsky, A., Brukental, I. and Landau, S. 1998. Selection of diets by dual purpose Mamber goats in Mediterranean woodland. J. Agr. Sci-cambridge, 131: 221-228.

Mathema, P. 1991. Focus on oak forest. Banko Janakari, 3(1): 13-16.

Meuret, M., Boza, J., Narjisse, N. and Nastis, A. 1990. Evaluation and utilization of rangeland feeds by goats. In: Morand Fehr, P. (ed.) Goat Nutrition Wageningen, The Netherlands.

Moktan, M.R. 2014. 'Social and Ecological Consequences of Commercial Harvesting of Oak for Firewood in Bhutan'. Mt. Res. Dev., 34(2):139-146.

Negi, S.S. and Naithani, H.B. 1995. Oaks of India, Nepal and Bhutan. Dehradun: International Book Distributors. ISBN: 8170892333.

Orwa, C., Mutua, A., Kindt, R., Jamnadass, R. and Anthony, S. 2009. Agroforestree Database: a tree and selection guide version 4.0. http://www.worldagroforestry. org/sites/ treedbs /treedatabases.asp.

Pandey, R.K. and Makkar, H.P.S. 1991. Variation of Tannins in Oak Leaves. Biochem Physiol Pflanz., 187(5): 392-394.

Papachristou, T.G. and Nastis, A.S. 1996. Influence of deciduous broadleaved woody species in goat nutrition during the dry season in Northern Greece. Small Rumin. Res., 20: 15.

Perevolotsky, A., Landau, S., Kababya, D. and Ungor, E.D. 1998. Diet selection in dairy goats grazing woody Mediterranean range land. Appl. Anim. Behav. Sci., 57: 117-131.

Rai, I.D., Padalia, H., Singh, G., Adhikari, B.S. and Rawat, G.S. et al. 2020. Vegetation dry matter dynamics along tree line ecotone in Western Himalaya, India. Tropical Ecology, 61: 116-127.

Roder, W., Dorji, K. and Gratzer, G. 2003. 'Nutrient flow from the forest - source of life for traditional Bhutanese agriculture'. Austrian J. For. Sci., 1: 65-72.

Saklani, K.P. 1999. Altitudinal and seasonal variation in relation to fodder quality of oak (Quercus leucotrichophora A. Camus ex. Bahadur) in Garhwal Himalaya. D.Phil. Thesis, H.N.B. Garhwal University, Srinagar, Uttaranchal, pp. 111.

Shrestha, B.B. 2003. Quercus semecarpifolia Sm. in the Himalayan region: Ecology, exploitation and threats. Himalayan J. Sci., 1(2): 126-128.

Shrestha, R.K. and Paudel, K.C. 1996. Oak forest under threat: An urgent concern for the mountain environment. In: Jha PK, GPS Ghimire, SB Karmacharya, SR Baral and P Lacoul (eds), Environment and biodiversity: In the context of South Asia. Kathmandu. ECOS.114- 119.

Singh, P., Biswas, J.C., Somvanshi, R., Verma, A.K., Deb, S.M. and Dey, R.A. 1996. Performance of pashmina cheghu. goats fed on oak_Quercus semecarpifolia. leaves. Small Rumin. Res., 22: 123-130. 
Singh, J.S. 2006. Sustainable development of the Indian Himalayan region:Linking ecological and economic concerns. Curr. Sci., 90(6): 784-788.

Singh, B. and Todaria, N.P. 2012. Nutrients composition changes in leaves of Quercus semecarpifolia at different seasons and altitudes. Ann. For. Sci., 55(2): 189-196.

Singh, J.S. and Singh, S.P. 1986. Structure and function of the Central Himalayan Oak forests. Proceeding of Indian National Science Academy (Plant Science) 96: 156-189.

Singh, J.S. and Singh, S.P. 1992. Forest of Himalaya. Gyanodaya Prakashan, Nainital. https:/www.worldcat. org/title/forests-of-himalaya-structure-functioning-andimpactof man/oclc/28220597.

Singh, S.P. 1998. Chronic disturbance, a principal cause of environmental degradation in developing countries (Editorial). Environ. Conserv., 25: 1-2.
Smith, O.B. 1992. Fodder trees and fodder shrubs in range and farming systems in tropical humid Africa. In: (eds. Speedy A., Pugliese P. L.). Legume trees and other fodder trees as protein sources for livestock FAO Animal Production and Health Paper 102:43-60.

Subedi, M.N. 2006. Conservation and sustainable utilization of oak (Quercus semecorpofolia Sm.) forest in Nepal. Bulletin of Department of Plant Resources, 27: 44-50.

Troup, R.S. 1921. The silviculture of Indian trees Clarendon Press, Oxford, UK pp. 1195.

Upreti, N., Tiwari, J.C. and Singh, S.P. 1985. The oak forest of Kumaun Himalaya (India): Composition, diversity and regeneration. Mount. Res. Dev., 5(2): 163-74.

Valdia, K.S. 1998. Dynamic Himalaya. Haidarabad: University Press Ltd. pp. 178. 
